\title{
Socio-Economic Characteristics and Extension Intervention of Livestock Farmer in Jalandhar District of Punjab, India
}

\author{
Rohit Gupta ${ }^{1 *}$, Kuldeep Singh ${ }^{2}$, Pragya Bhadauria ${ }^{3}$ and Yogendra S. Jadoun ${ }^{4}$ \\ ${ }^{1}$ Krishi Vigyan Kendra, Jalandhar, (Punjab Agriculture University, Ludhiana), \\ Pin: 144039, India \\ ${ }^{2}$ Krishi Vigyan Kendra, Jalandhar, India \\ ${ }^{3}$ ATARI, Zone-I, PAU Campus, Ludhiana, India \\ ${ }^{4}$ GADVASU, Ludhiana, India \\ Punjab Agriculture University, Ludhiana, Krishi Vigyan Kendra, Jalandhar, India \\ *Corresponding author
}

\section{A B S T R A C T}

\begin{tabular}{l} 
Key w o r d s \\
Credibility, \\
$\begin{array}{l}\text { Extension activities, } \\
\text { Livestock farmer, } \\
\text { Socio-economic } \\
\text { status }\end{array}$ \\
\hline Article Info \\
$\begin{array}{l}\text { Accepted: } \\
\text { 22 June } 2020 \\
\text { Available Online: } \\
\text { 10 July } 2020\end{array}$ \\
\hline
\end{tabular}

A vigilant study of the socioeconomic aspects of livestock farmers is a prerequisite for the appropriate design and successful execution of Governments' developmental programmes. The present study was conducted to assess the socio-economic status and credibility of various extension activities among the livestock farmers. For this, primary data collected through structured interview schedule using a sample size of 150 respondents from Jalandhar district of Punjab. Results of the study revealed that majority of the farmers belong to middle age $(62.00 \%)$ group, medium size $(65.30 \%)$ of family, medium size $(67.30 \%)$ of livestock holding, medium range $(50.70 \%)$ of income group and low risk orientation (45.30\%). Most of the respondents $(92.70 \%)$ have their strong linkage with Panchayat members and participation in various extension activities was found highest (19.10\%) among young farmers. Majority of the farmers participated in Kisanmelas $(68.70 \%)$ albeit relative credibility index found highest for demonstration activity. Hence efforts should be undertaken by the Government, Veterinary Universities and other extension agencies in providing information on improved livestock farming practices and more emphasis should be given on learning by doing, result oriented extension activities and strong farmer-extension-research-linkages so that farmers could bring about change in their living standard and can improve their socio-economic status.

\section{Introduction}

The livestock sector is one of the fastest growing segments of the agricultural economy, particularly in the developing country like India which provides nutritive food rich in animal protein and it also helps in supplementing family incomes and generating gainful employment for 70.0 million farm families of landless, marginal and small farmers. Animal husbandry is second largest economical activity in rural India next to agriculture. Livestock sector is directly related to a more balanced development of 
rural economy and upliftment of poorer sections of the society. Despite of rapid advances in the animal husbandry technologies and their roles in improving livestock sector, the productivity of this sector is still very low in India (Chander et al., 2010) which may be due to various reasons like poor adoption and diffusion of new technologies and poor knowledge level of farmers. Most of the farmers are not aware of scientific livestock management practices and adoption of improved animal husbandry practices which is very essential for the growth of livestock economy (Aulakh and Singh, 2015). Indian livestock industry has a unique characteristic that the bulk of animal produce is handled by small farmers who are illiterate and ignorant of commercial and economic aspects of livestock production. Thus a vigilant study of the socio-economic status of livestock farmers is a prerequisite and need of the hour for the legitimate design and well-tuned execution of any developmental plan at field level. Therefore the present study was undertaken with the objective to assess the socio- economic status of livestock farmer and their approach to extension personnel for gather the information of livestock managemental practices so that further need based livestock developmental interventions can be supplemented to the end users.

\section{Materials and Methods}

The study was conducted in Jalandhar district of Punjab state. 10 villages from two blocks were selected for the study purpose and from these villages 15 livestock farmers were randomly scrutinized for interview, thus sample size of this study was 150. A wellstructured pre-tested interview schedule was used for collection of data and the data was analyzed by using appropriate statistical methods. The information on socio-economic status and extension intervention was collected through this personal interview, observation and available secondary resources. Socio-economic information comprises educational status, age, land holding, herd size, herd composition, annual income, social participation, risk orientation and decision making. Information regarding extension interventions viz; demonstration, training, awareness camp, Kisanmelas and field days was also collected. Credibility index were calculated for measuring the reliability of extension activity by the farmer. Out of given sources of information, the respondents were asked to indicate only the most and least credible activity related to animal husbandry. The relative credibility index was worked out with the following formula (Sandhu, 1973).

Relative credibility index $=(\mathrm{X} / \mathrm{Y}) \times(100 / \mathrm{N})$ $\mathrm{X}=$ Number of respondents who believed a source most credible $\mathrm{Y}=$ Number of respondents who believed a source least credible $\mathrm{N}=$ Total number of respondents.

The collected data were accumulated, grouped and interpreted according to the objectives of the study. All the data were compiled in Microsoft Office Excel and analyzed by using appropriate statistical tools like frequency, percentage, mean, standard deviation etc.

\section{Results and Discussion}

\section{Socio-economic characteristics of the respondents}

It could be observed from the table 1 that more than half $(62.00 \%)$ of the farmers involved in livestock farming belonged to middle age group followed by old $(25.30 \%)$ and young $(12.70 \%)$ age group. The reason for the majority being in the middle age group might be due to the ancestral forwarded rituals of farming which were related to ethnics of the society. However very less were in young group due to the less 
agricultural productivity and migrations of youths for jobs in factories to earn their livelihood. It was also revealed that young ones were not interested in performing various agriculture related activities and still elder were taking care of the land owned by them. The main reason for this situation noticed was very low profitability followed by huge initial investment and highly labour intensive task particularly at small level in the villages. These findings were in agreement with Shekhawat et al., (2013).

It is reveled from Table 1 that about 84.00percent respondents had level of education in between primary to higher secondary. Only 2.70percent of family head was found illiterate and 8.00 percent respondent were had formal education with reading or writing only. Likewise only 5.30percent of farmer were graduated or having higher education. Reason behind these finding were observed that less belief in higher education due to shortage of secured jobs. The results are in line with the earlier findings of Gogoi and Phukan (2000).

Perusal the data presented in table 1 shows that 31.30percent and 34.70percent of farmers were belongs to marginal and small land holding categories, respectively. Only 6.70percent farmers categorized as large farmer which were owned more than 10 acre of agriculture land and 20.00 percent farmer were having 5 to 10 acres of land holdings and only 07.30percent of farmer fall in the category of landless farmers.

The reason attributed for the majority of livestock farmers belong to marginal and small farmer's category could be due to subdivision and fragmentation of the land within the family, which is a common phenomenon in the nuclear family system than the traditional joint family system (Sathyanarayan et al., 2010).
Most of the farmers belong to medium (65.00 $\%)$ size family having 5 to 8 members followed by small $(24.00 \%)$ and large family $(10.70 \%)$. higher side of medium size of family imply the migration of youth and division of the family as advancement of the generations. Similar trend was observed by Kavitha and Reddi (2007).

Majority of respondents were keeping medium size $(65.30 \%)$ of herd of dairy animals followed by small $(24.00 \%)$ and large size herd $(5.30 \%)$ as revealed in the Table 1. Most of the respondent carrying dairy as their family tradition and they are only maintaining herd what they got from their forefathers. Possession of medium herd may be indicative of the fact that it might be due to small land holding coupled with scarcity of green fodder round the year. Due to less profit (as they think) most of the respondent not willing to expend their herd size as reported by Sharma et al., (2009). Some respondent keeping dairy animals only for meeting out their family milk requirement, surplus milk they sold locally. Only few farmers as reported keeping large size of dairy herd, and they are also willing to commercialize their dairy farm for earning maximum profit. Present observations are in agreement with the results of Senthilkumar et al., (2006).

With regard to herd composition, majority $(62.70 \%)$ of the respondents possessed cross bred cow followed by upgraded buffalo (56.00 \%), Pure Breed Buffalo (32.70 \%), Exotic cattle $(31.30 \%)$ and only 15.30percent and 24.30percent respondent possessed Indigenous cattle and Non descriptive cattle, Respectively. The study also revealed that few farmers were interested to go for commercial dairy farming. This might be due to the fact that there are number of bottlenecks in dairy farming as reported by Sharma et al., (2009). Very few of the 
respondent (7.30 \%) having piggery as a subsidiary occupation. Goat and Poultry were also contributing in the herd composition of the respondent, in which 9.30percent respondent having goat and 33.40percent respondent maintaining poultry in their livestock herd. Out of 33.40percent of poultry farmers majority $(30.70 \%)$ of them keeping poultry as their backyard for household consumption, only negligible $(2.70 \%)$ respondent keeping poultry as a commercial venture. 2.70percent and 16.00percentof respondent had horse and dogs as companion animals. Out of all respondents, 2.00percent farmer also possessed fisheries as commercial enterprises. Higher percentage of cross breed cattle and upgraded buffalo possession indicates awareness of farmers regarding importance of breeds of animals. Contribution of piggery and goatery imply that farmers are willing to fetch livestock income from other than dairy livestock due to uncertainty in the milk price and seasonal fluctuation in the milk production. The result was in conformity with that of Ravikumar (2006). Analysis of the data presented in Table 1 also revealed that 45.30percent of respondent having very low risk orientation followed by medium $(28.00$ $\%)$ and higher $(26.70 \%)$ risk orientation attitude. Usually middle aged group of people were more enthusiastic, having risk bearing capacity, eager to learn and they are innovative in nature. Similar results were reported by Hanumanaikar et al., (2006).

Table 1 also unfolds the income status of the respondent. Maximum (50.70\%) respondent were in the medium level of income group followed by low $(29.30 \%)$ and higher $(20.00 \%)$ income group. This could be due to less risk bearing by majority of respondent and they were also not willing to extend their livestock enterprises and they generated their income only from herd they possessed. It is also evident that (Table 1) most of the livestock farmer were found in medium
$(42.70 \%)$ category of social participation followed by low (36.70\%) and high $(21.30 \%)$ social participation. This could be due to less awareness and lack of continuous motivation of farmer to be in the part of social activities. This was the accordance with the finding of Naberia et al., (2011). The surprising element of this study was in decision making activities in the family i.e., in contrast to usual consideration in male dominant society, 51.30percentof the family decision were taken collectively followed by 40.70percent family decisions were taken by male and only 8.00percent family decision were taken by women alone. The findings were in consonance with the findings of Boseet. al. (2013).

\section{Distribution of respondents on the basis of their Extension Contacts with livestock felicitator}

In this study it has observed that farmer extension contact play important role in their livestock farming practices. Table 2 revealed that maximum number $(92.70 \%)$ of farmers had had their contact with village panchayat sarpanch or members and ranked I. Out of these 46.00percent contacted village sarpanch in regular basis and the reason behind this is this local people can easily share their feelings with the local leaders or panchayat members. Further contact of respondent with input dealer from nearby town, Banks and insurance personnel, Animal Husbandry officials, Veterinary hospitals / A.I. Centers, KVK officials, Veterinary college/Institutes, Dairy Mela/ KisanMela, NGOs and SHGs and ranked II, III, IV, V, VI, VII, VIII, IX and X rank respectively. Input dealers are mainly locally person or person from within the farmers who could approach farmer at any time and it was ranked as second highest linkage with respondents. Most of the farmers had their account in village level cooperative bank so they were able make frequently 
contact with the bank/insurance personnel. Farmers contact with Animal Husbandry officials (70.00\%), Veterinary clinic (67.30 $\%)$ and KVK official (62.00\%) had not shown too much difference and in these mostly official make contact with the farmers for disseminate the information regarding scientific livestock farming practices or make farmers aware through various awareness programs, trainings and others extension activities due to distantly location of veterinary college/institute and place of Kisanmela and only 39.30 percent and 36.00percent farmer were able to visit these two place, respectively and only 4.00percent and 2.70percent respondents had liaison with SHGs and NGOs respectively. The major reason behind few contacts with these institutes reflects the individual working attitude of the respondent as reported by Ravishankar et al., (2014).

\section{Involvement of the respondents in various extension activities}

It is revealed from table 3 that most of the farmers were showing enthusiasm toward Kisanmelas which is organized by various government organizations and was found that 68.70percent of farmers have participated in Kisanmelas. The least participation was observed in the field days $(27.30 \%)$ activities and the possible reason behind this is the, very few organization conducted such kind of activity and on some exclusive topic only thus attracts only specific participants.

Table.1 Socio-economic characteristic of the respondents $(\mathrm{N}=150)$

\begin{tabular}{|c|c|c|c|}
\hline S.No. & Personal Characteristic & Frequency & Percentage \\
\hline 1 & \multicolumn{3}{|l|}{ Age } \\
\hline & Young Age $(<35)$ & 19 & 12.70 \\
\hline & Middle Age (35 - 55) & 93 & 62.00 \\
\hline & Old Age $(>55)$ & 38 & 25.30 \\
\hline \multirow[t]{9}{*}{2} & \multicolumn{3}{|l|}{ Educational qualification } \\
\hline & Illiterate & 04 & 02.70 \\
\hline & Can read only & 04 & 02.70 \\
\hline & Can read and Write & 08 & 05.30 \\
\hline & Up to Primary & 28 & 18.70 \\
\hline & Middle & 39 & 26.00 \\
\hline & High School & 35 & 23.30 \\
\hline & Higher Secondary & 24 & 16.00 \\
\hline & Graduate and above & 08 & 05.30 \\
\hline \multirow[t]{4}{*}{3} & \multicolumn{3}{|l|}{ Family size } \\
\hline & Small (1-4) & 36 & 24.00 \\
\hline & Medium (5-8) & 98 & 65.30 \\
\hline & Large $(>8)$ & 16 & 10.70 \\
\hline \multirow[t]{4}{*}{4} & \multicolumn{3}{|l|}{ Land holding } \\
\hline & Land less (No Land ) & 11 & 07.30 \\
\hline & Marginal (Up to 2.5 acres) & 47 & 31.30 \\
\hline & Small (above 2.5 to 5 acres) & 52 & 34.70 \\
\hline
\end{tabular}




\begin{tabular}{|c|c|c|c|}
\hline & $\begin{array}{l}\text { Medium (above } 5 \text { to } 10 \\
\text { acres) }\end{array}$ & 30 & 20.00 \\
\hline & Large (above 10 acres) & 10 & 06.70 \\
\hline \multirow[t]{4}{*}{5} & \multicolumn{3}{|l|}{ Herd size (Dairy Animals) } \\
\hline & Small Herd Size (Up to 2) & 20 & 13.30 \\
\hline & Medium Herd Size (3 to 7 ) & 101 & 67.30 \\
\hline & $\begin{array}{l}\text { Large Herd Size ( } 8 \text { and } \\
\text { above) }\end{array}$ & 29 & 19.30 \\
\hline \multirow[t]{14}{*}{6} & \multicolumn{3}{|l|}{ Herd composition } \\
\hline & Indigenous Cattle & 23 & 15.30 \\
\hline & Nondescriptive Cattle & 36 & 24.00 \\
\hline & Cross Breed Cattle & 94 & 62.70 \\
\hline & Exotic cattle & 47 & 31.30 \\
\hline & Pure Breed Buffalo & 49 & 32.70 \\
\hline & Upgraded Buffalo & 84 & 56.00 \\
\hline & Goat & 14 & 09.30 \\
\hline & Poultry (Backyard) & 46 & 30.70 \\
\hline & Poultry (commercial) & 04 & 02.70 \\
\hline & Piggery & 11 & 07.30 \\
\hline & Horse & 04 & 02.70 \\
\hline & Fisheries & 03 & 02.00 \\
\hline & Dog & 24 & 16.00 \\
\hline \multirow[t]{4}{*}{7} & \multicolumn{3}{|l|}{ Annual income } \\
\hline & Low (up to 60000) & 44 & 29.30 \\
\hline & Medium ( 61000 to 150000 ) & 76 & 50.70 \\
\hline & High (151000 and above) & 30 & 20.00 \\
\hline \multirow[t]{4}{*}{8} & \multicolumn{3}{|l|}{ Social participation } \\
\hline & Low Social participation & 55 & 36.70 \\
\hline & Medium Social participation & 64 & 42.70 \\
\hline & High Social participation & 32 & 21.30 \\
\hline \multirow[t]{4}{*}{9} & \multicolumn{3}{|l|}{ Risk orientation } \\
\hline & Low (Score up to 15$)$ & 68 & 45.30 \\
\hline & Medium (Score 16 to 25 ) & 42 & 28.00 \\
\hline & $\begin{array}{l}\text { High Score (Score } 26 \text { and } \\
\text { above) }\end{array}$ & 40 & 26.70 \\
\hline \multirow[t]{4}{*}{10} & \multicolumn{3}{|l|}{ Decision maker of the family } \\
\hline & Men & 61 & 40.70 \\
\hline & Women & 12 & 08.00 \\
\hline & Together & 77 & 51.30 \\
\hline
\end{tabular}


Table.2 Extension contact of livestock farmer in the Jalandhar district $(\mathrm{N}=150)$

\begin{tabular}{|c|c|c|c|c|c|c|}
\hline \multirow[b]{2}{*}{ Particulars } & \multicolumn{6}{|c|}{ Frequency (Percentage) } \\
\hline & Regularly & $\begin{array}{l}\text { Most } \\
\text { often }\end{array}$ & Sometimes & Never & $\begin{array}{l}\text { Total } \\
\text { Visited }\end{array}$ & Rank \\
\hline Animal Husbandry officials & $\begin{array}{c}22 \\
(14.70)\end{array}$ & $\begin{array}{c}42 \\
(28.00)\end{array}$ & $\begin{array}{c}41 \\
(27.30)\end{array}$ & $\begin{array}{c}45 \\
(30.00)\end{array}$ & $\begin{array}{c}105 \\
(70.00)\end{array}$ & IV \\
\hline Village Panchayat Members & $\begin{array}{c}69 \\
(46.00)\end{array}$ & $\begin{array}{c}37 \\
(24.70)\end{array}$ & $\begin{array}{c}33 \\
(22.00)\end{array}$ & $\begin{array}{c}11 \\
(07.30)\end{array}$ & $\begin{array}{c}139 \\
(92.70)\end{array}$ & $\mathrm{I}$ \\
\hline $\begin{array}{l}\text { Veterinary hospitals / A.I. } \\
\text { Centers }\end{array}$ & $\begin{array}{c}17 \\
(11.30)\end{array}$ & $\begin{array}{c}18 \\
(12.00)\end{array}$ & $\begin{array}{c}66 \\
(44.00)\end{array}$ & $\begin{array}{c}49 \\
(32.70)\end{array}$ & $\begin{array}{c}101 \\
(67.30)\end{array}$ & V \\
\hline KVK / ATIC officials & $\begin{array}{c}27 \\
(18.00)\end{array}$ & $\begin{array}{c}46 \\
(30.70)\end{array}$ & $\begin{array}{c}20 \\
(13.30)\end{array}$ & $\begin{array}{c}57 \\
(38.00)\end{array}$ & $\begin{array}{c}93 \\
(62.00)\end{array}$ & VI \\
\hline Input Dealers from nearby town & $\begin{array}{c}36 \\
(24.00)\end{array}$ & $\begin{array}{c}56 \\
(37.30)\end{array}$ & $\begin{array}{c}16 \\
(10.70)\end{array}$ & $\begin{array}{c}42 \\
(28.00)\end{array}$ & $\begin{array}{c}108 \\
(72.00)\end{array}$ & II \\
\hline KisanMela & $6(4.0)$ & $\begin{array}{c}7 \\
(04.70)\end{array}$ & $\begin{array}{c}41 \\
(27.30)\end{array}$ & $\begin{array}{c}96 \\
(64.00)\end{array}$ & $\begin{array}{c}54 \\
(36.00)\end{array}$ & VIII \\
\hline Veterinary college/Institutes & $\begin{array}{c}23 \\
(15.30)\end{array}$ & $\begin{array}{c}9 \\
(06.00)\end{array}$ & $\begin{array}{c}27 \\
(18.00)\end{array}$ & $\begin{array}{c}91 \\
(60.70)\end{array}$ & $\begin{array}{c}59 \\
(39.30)\end{array}$ & VII \\
\hline Banks and insurance personnel & $\begin{array}{c}27 \\
(18.00)\end{array}$ & $\begin{array}{c}17 \\
(11.30)\end{array}$ & $\begin{array}{c}62 \\
(41.30)\end{array}$ & $\begin{array}{c}44 \\
(29.30)\end{array}$ & $\begin{array}{c}106 \\
(70.70)\end{array}$ & III \\
\hline $\begin{array}{l}\text { Non-Government Organizations } \\
\text { (NGOs) }\end{array}$ & $\begin{array}{c}0 \\
(0.0)\end{array}$ & $\begin{array}{c}0 \\
(0.0)\end{array}$ & $\begin{array}{c}4 \\
(02.70)\end{array}$ & $\begin{array}{c}146 \\
(97.30)\end{array}$ & $\begin{array}{c}4 \\
(02.70)\end{array}$ & $\mathrm{X}$ \\
\hline Self Help Groups (SHGs) & $\begin{array}{c}0 \\
(0.0)\end{array}$ & $\begin{array}{c}0 \\
(0.0)\end{array}$ & $\begin{array}{c}6 \\
(04.00)\end{array}$ & $\begin{array}{c}144 \\
(96.00)\end{array}$ & $\begin{array}{c}6 \\
(04.00)\end{array}$ & $\mathrm{XI}$ \\
\hline
\end{tabular}

Figures in parenthesis indicate percentage of the respondents.

Table.3 Involvement of respondent in different personal cosmopolite channel of livestock information for transfer of technology $(\mathrm{N}=150)$

\begin{tabular}{|l|c|c|c|c|}
\hline \multirow{2}{*}{ Extension Activities } & \multicolumn{4}{|c|}{ Age group of farmers in years (\% of respondent) } \\
\cline { 2 - 5 } & $18-30$ & $30-45$ & $>45$ & Total \\
\hline Demonstrations & 35 & 14 & 10 & 59 \\
\hline Field days & $(23.30)$ & $(09.30)$ & $(06.70)$ & $(39.30)$ \\
\hline Awareness Camp & 19 & 9 & 13 & 41 \\
& $(12.70)$ & $(6.00)$ & $(08.70)$ & $(27.30)$ \\
\hline KisanMelas & 18 & 27 & 16 & 61 \\
& $(12.00)$ & $(18.00)$ & $(10.70)$ & $(40.70)$ \\
\hline Training programs & 45 & 33 & 25 & 103 \\
& $(30.00)$ & $(22.00)$ & $(16.70)$ & $(68.70)$ \\
\hline Overall Participation & 26 & 24 & 12 & 62 \\
& $(16.00)$ & $(16.00)$ & $(8.00)$ & $(41.30)$ \\
\hline
\end{tabular}


Table.4 Relative Credibility of personal cosmopolite channel of livestock information for transfer of technology $(\mathrm{N}=150)$

\begin{tabular}{|l|c|c|c|c|}
\hline \multirow{2}{*}{ Extension Activities } & \multicolumn{4}{|c|}{ Relative Credibility } \\
\cline { 2 - 5 } & $\begin{array}{c}\text { High } \\
(\text { Score })\end{array}$ & $\begin{array}{c}\text { Low } \\
(\text { Score })\end{array}$ & $\begin{array}{c}\text { Relative } \\
\text { Credibility Index }\end{array}$ & Rank \\
\hline Demonstrations & 32 & 27 & 0.79 & I \\
\hline Field days & 19 & 22 & 0.58 & III \\
\hline Awareness Camp & 26 & 35 & 0.50 & IV \\
\hline KisanMelas & 39 & 64 & 0.41 & V \\
\hline Training programs & 32 & 30 & 0.71 & II \\
\hline
\end{tabular}

In between of these two activities about 41.30percent, 40.70percent and 39.3 percent participated in trainings, awareness camps and demonstrations respectively. Overall participation in various extension activities was found only 43.50percent in which maximum participation $(19.10 \%)$ was shown by young generation which fall in the categories of $18-30$ years of age followed by middle age $(14.30 \%)$ farmers and old age $(10.10 \%)$ farmers. Youth or young generation has demonstrated the keen interest in learning of new technologies thus shown maximum participation in various activities. Old group of farmers were found to have laggard attitude and not willing to take any risk, so their participation marked as least in extension activity and these findings were in-line with the results of Ravikumar (2006).

Credibility index had shown (Table 4) some different picture of reliability of various extension activities. Respondent had been perceived differently for different methods of transfer of technology. It was found that demonstration method had highest relative credibility index (0.79) which shown that maximum farmers rely on this method followed by training programs (0.71), field days (0.58), awareness camps (0.50) and Kisan Melas (0.41). Higher index value of demonstrations and training programs were due to their practical and result oriented nature and these finding were the accordance with the results of Chaudhary and Khan, (2017).

In conclusion, the socio-economic characteristics of the farmers are important for better policymaking decisions. Study revealed that more than half of the farmers involved in livestock farming belonged to middle age and medium level of income group. Due to low agricultural profitability, young people are not interested in agriculture and shift towards other allied business and service activities. Although they are having experimental nature and very keen to learn new things about scientific livestock farming practices (breeding, feeding, healthcare and management aspects) easy loan, credit facility and marketing linkage can develop their faith in the livestock related entrepreneurial ventures. Additionally result oriented demonstration procedure would enhance the intellectuality regarding animal husbandry practices and would bring about some change in the attitude of livestock young farmers. Therefore extension services should be more focused on skill development trainings and demonstrations of advanced proven livestock technologies at the farmers field. The findings 
of this study would help the development workers, administrators and policy planners in effective implementation of livestock and poultry development programmes by mitigating the identified bottlenecks and the academic significance of this study lies in developing and standardizing tools to measure socio-economic impact as well as on the production and reproduction of various livestock based enterprises.

\section{References}

Aulakh, G. S. and Singh, R. 2015. Socioeconomic characteristics of farmers and status of buffalo health care practices. Indian Journal of Animal Sciences. 85(12): 1396-1398.

Bose D.K., Srivastava, J.P., Masih, E. and Bose, H. 2013. Participation of rural women in livestock management activities in coochbehar district of West Bengal. Indian Journal of Extension Education. 49 (1 \& 2): 40-42.

Chander, M., Dutt, T., Ravikumar, R. and Subrahmanyeswari, B. 2010. Livestock technology transfer service in India: A review. The Indian Journal of Animal Science. 80: 1115-1125.

Choudhary, S. and Khan, I. M. 2017. Credibility of different agriculture information sources and channels utilized by the anolag rowers. International Journal of Current Microbiology and Applied Sciences. 6(7): 2277-2288.

Gogoi, M. and Phukan, E. 2000. Extent of adoption of improved rice cultivation practices by farmers. Maharashtra Journal of Extension Education. 19: 190-193.

Hanumanaikar, R. H., Rajeshwari, N. and Nimbal, M. F. 2006. Socio economic status, constraints faced and suggestions expressed by the chilli growers in optimum use of pesticides in
Thungabhadra project area of Bellary district. Mysore Journal of Agriculture Science. 40: 261-266

Kavitha, L. and Reddi, M. S. 2007. Personal and Socio-Economic Characteristics of Farm Women. Journal of Research ANGRAU. 35(1): $79-83$.

Naberia, S., Gautam, U.S. and Gupta, A. K. 2011. Socio-economic factors influencing adoption of low cost agricultural technologies. Indian Journal of Extension Education. 47(3 \& 4): 115119.

Ravikumar, R. K. 2006. Livestock extension activities under the State Departments of Animal Husbandry in India: An institutional analysis.' Ph.D. thesis, Indian Veterinary Research Institute, Izatnagar.

Ravishankar,H., Naidu, V.S.G.R.,Sivaraju, K., Babu, B.J. and Sivarao P.V.V.S.2014. Expert system for dairy cattle management, Indian Journal of Animal Sciences. 84 (8): 891-896

Sandhu, A. S. 1973. Relative efficiency of four methods of measuring credibility of farm information source. Indian Journal of Extension Education. 9(1): 71-74.

Sathyanarayan, K., Jagadeeswary, V., Chandrashekhar Murthy, V., Wilfred Ruban, S. and Sudha, G. 2010. Socioeconomic Status of Livestock farmers of Narasapura Village - A Benchmark Analysis, Veterinary World. 3(5): 215218.

Senthilkumar, T., Sudeepkumar, N. K., Subramanian, R. 2006. Personal and socio-economic characteristics of urban dairy farmers utilizing mobile artificial insemination services. Tamil Nadu Journal of Veterinary and Animal Sciences. 2(6): 220-223.

Sharma, K., Singh, S. P. and Yadav, V. P. S. 2009. Knowledge of dairy farmers about improved buffalo husbandry 
management practices. Indian Research Journal of Extension Education. 9(3):51-54.

Shekhawat, L. S., Mahajan, K. C. and Jaiswal,
A. 2013.Cattle owners and their extent of knowledge about individual animal husbandry practices. Journal of Progressive Agriculture. 4(2): 41-44.

\section{How to cite this article:}

Rohit Gupta, Kuldeep Singh, Pragya Bhadauria and Yogendra S. Jadoun. 2020. SocioEconomic Characteristics and Extension Intervention of Livestock Farmer in Jalandhar District of Punjab, India. Int.J.Curr.Microbiol.App.Sci. 9(07): 3722-3731. doi: https://doi.org/10.20546/ijcmas.2020.907.436 